\title{
Practical Work by Laboratory Stations: An Innovation in Experimental Work
}

\author{
Isabel Ribau \\ Department of Applied Social Sciences, School of Science and Technology, Universidade NOVA de Lisboa (NOVA), Portugal
}

Received September 3, 2019; Revised November 22, 2019; Accepted December 17, 2019

Copyright $\bigcirc 2020$ by authors, all rights reserved. Authors agree that this article remains permanently open access under the terms of the Creative Commons Attribution License 4.0 International License

\begin{abstract}
Experimental work is essential for the development of scientific skills and student motivation. However, students are not always involved in the experimental work, and the development of scientific skills is compromised. In this study, the model of experimental teaching of Chemistry and Physics by laboratory stations is presented and its contribution to the promotion of self-efficacy and self-regulation is discussed. This model had underlying active learning, neuroeducation and was developed using a collaborative Peer Instruction approach. The regular use of laboratory stations during two years, in two classes of basic education, allowed not only counteracting the distance between the students and Physics and Chemistry but also improving the students' engagement in classrooms. The purposes of this implementation were to develop students' Chemistry and Physics knowledge, to engage students in the classroom activities, and develop scientific skills (handling equipment, making and describing observations, recording data, gave meaning to measurements, obtaining experimental results, discuss and analyse results, planning experiments to verify hypotheses). The promotion of collaborative work habits among students, critical thinking and the debate between peers as strategies to achieve significant learning were also other aims of this methodology.
\end{abstract}

Keywords Practical Work, Classroom Management, Peer Instruction, Laboratory Stations

\section{Introduction}

This study case reports the implementation of an experimental/practical work methodology, which has repercussion in all classroom work, during two years and bring benefits for students.

The implementation of this methodology started as a teacher needs to engage students in science class. There were several problems, diagnoses by the teachers in the school, not only related to scientific skills not developed during the classroom, but also to the discrepancy between students expectations regard to school and classroom. Another difficulty was the students focus in the classroom work, even if it was experimental work, which was a barrier for time management and for student engagement in the classroom activities. The number of students that followed the scientific area in the 10th was low, and the results in national exams were poor. To decrease the gap between students expectations and the learning process in science classroom, and after a review of methodologies that could be implemented, using no additional money or equipment, allowing using in different classrooms and with few materials/apparatus, the Lab Station approach was chosen, not only by their space and apparatus versatility but also by the reported advantages (Mota, 2012).

Science teaching implies, among other things, curriculum management, teacher autonomy, teaching competencies and scientific knowledge. To develop students' scientific skills, the teacher must use in their classroom practical work, namely experimental work, and strategies to involve students in classroom tasks. The choice of classroom activities and tasks, as well as classroom methodologies, frames into the teacher autonomy and in their didactic and pedagogical skills, abilities and competencies.

To learn sciences students must be, in a learning environment, enrolled in activities that help them to connect with the science content and promote intrinsic motivation. So the question that arises is "What kind of tasks engages students?"

In this paper, we present a methodology that engages students and is different from the traditional experimental work in classrooms. Is an active learning process (not because the student is doing practical work, but because the student is the central piece of the learning process and is engaged in the activities), is space versatile (it can be 
applied in a normal classroom, or even in an open space outside the room- in the field) is ecological (it can be applied with everyday materials) and cheaper (is only necessary have um kit per lab station).

In the classroom, students are the centre of the learning process. During the class students have different activities that must be done in a defined time (they must learn how to manage time), implying not only that students must focus on the tasks and work collaboratively, but also that students must prepare themselves previously at home to do the experiments (inverted classroom).

The teacher is an organizer and a provider of learner environments: he organizes the worksheet (the tasks), the materials and the classroom space. During the classroom, he will support students, clarifying doubts, going through the different groups raising questions related to the activities that are being developed, and control time.

\section{Literature Review}

\subsection{Teacher Autonomy and Curriculum Management}

There are three essential concepts related to the curriculum operationalization in the classroom: the curriculum himself, the curriculum management and the teacher autonomy. The teacher curriculum management implies, the teacher curriculum concept (learning contents, goals and activities to achieve them, students assessment), the school organization (sequence and schedule, collaborative work in the institution, teacher evaluation process), the school type of leadership (institution rules, routines and decisions), the teacher place in the organization. The results of the evaluation not only of the students (criteria, student assessment and evaluation) but also the teacher efficiency to promote the learning process (the evaluation strategies, the self-reflection, new goals) and in the end, the school assessment, are important items of the curriculum management. In this context, the teacher autonomy to develop strategies that provide students with tools to learn is very important once it knows the class's context (difficulties and strengths) and can use it to develop strategies. The teacher must use this autonomy in the classroom to apply different strategies and methodologies to achieve learning outcomes.

But contextualized the learning environment is not staying apart from the rest of the scholarly community. The Core Curriculum must be present in teacher minds when he/she plans classroom activities. In this sense core curriculum in science is the scientific competency, the abilities and skills, but also basic concepts of science that can be the support for more advanced knowledge.

\subsection{The Learning Issue}

The cognitive-constructivist perspective of learning is due to the Piagetian, Vygotsky model and Ausubel, Novak and Hanesian (1981). In perspective, the learner must learn to think and learn to learn, being the responsible for his learning course (Cachapuz, Praia \& Jorge, 2000; Vasconcelos, Praia, Félix \& Leandro, 2003).

In the assimilation theory of Ausubel et al. (1981) there are two dimensions of the learning process: how the knowledge to be learned is made available to the student (which can be by reception or by discovery) and how students incorporate this information into their existing cognitive structures (which can be mechanical or meaningful; If the learner attempts to retain new information, relating it to what he or she already knows, meaningful learning occurs; if the learner merely tries to memorize the new information, mechanical learning occurs). But the highlighting is placed on meaningful learning, that is, a process in which new information is related to a relevant aspect of the individual's knowledge structure (Ausubel et al., 1981). Meaningful learning occurs only when the new information (which presents a logical structure), interacts with previous knowledge (relevant and inclusive concepts available in the cognitive structure) and is anchored/connected to it becoming new knowledge. "If concepts, previous knowledge doesn't exist the learner must learn mechanically the new information. In this sense, the most important single factor influencing learning is what the learner already knows, and the strategy to teach him accordingly with it" (Moreira \& Masini, 1982: 9). During the learning process, the subject acquires knowledge which is organized in a cognitive structure related to each knowledge area. It is important also to consider the previous organizers (a general and inclusive cognitive structure that functions as a cognitive anchorage for the new one) if it doesn't exist previous knowledge in an area, which may help to anchor new learning and lead to learning. In this sense, previous organizers must be more general, more abstract, and more inclusive than the subsequent learning material. In this perspective at the level of curriculum development and planning, these more general elements must be introduced first, and the concept will be progressively differentiated in terms of detail and specificity.

\subsection{Neuroeducation}

One of the neuroeducation aims is to improve ways to teach based on confirmed best teaching practices through scientific evidence of how humans learn (Fisher, Coch \& Dawson, 2007; Goswami, 2006). It is possible to identify tenets and principles, but also instructional guideline from the literature, which constitutes the backbone of neuroeducation (Tokuhama-Espinosa, 2008, 77 to 81).

Neuroeducation has an interdisciplinary nature. It draws from neuroscience, psychology and pedagogy. Although these three areas have a different approach to the learning process, they share a common goal: explaining the learning 
process. In this context, the theories of human consciousness are important as they explain core concepts (how individuals know themselves and related to the world knowing the others). In this sense, metacognition is very important to improve and develop learning (Inchausti de Jou \& Sperb, 2006; Beber, Silva \& Bonfiglio, 2014; Rosa, 2014). Levine's argues that memory and attention are driving constructs in learning. This theory link psychological models of intelligence to biologically based models.

There are brain functions related not only to academic skills (art, creativity, language, math, music, reading, science) but also life skills (affect and empathy, attention, emotions, executive functions and decision-making, face recognition and interpretation, memory, motivation, sensory perception, social cognition, spatial management and time management) (Tokuhama-Espinosa, 2013). Some authors like Damásio $(1994,2000,2004)$ and LeDoux (2000) have analysed the connection between decision-making and emotion and concluded that there is no decision without emotion which will have consequences in the learning process. "We feel we learn" that's the key to engage students in the classroom. As Damásio refer students only learn if they relate themselves with the school values and rules. Students must know which way they should cross to be a part of society. Without values and the linkage to the scholarly community, students will not construct a sense of belonging, and they will not integrate themselves as a part of it. So before the discipline, the school must construct an image to them, with clear structure, organization, with values (cultural, contextualized and scientific) with rules, rights and duties. Only after that, students can engage themselves in chemistry or physics. But emotional states are also related to motivation. Neuroeducation studies related to motivation indicated that feedback from the others is essential to promote positive (or negative) motivation and that motivation is the key to create positive learning environments (Reeve, 2004; Bray, Shimojo \& O'Doherty, 2007). However, to be motivated to do something students must pay attention to it. So attention is also a pillar to engage students in the learning process (Levine, 2000; Sousa, 2000). At the individual's executive function (the way the brain manages decision-making) and the decision making, regulates attention, it is also important to emphasize that is the learners choose what to ignore or what to pay attention. Social cognition (a person's ability to work well with others) is also very important as a life skill. It influences the way an individual integrates and interact with the group. And as Mazur (1997) and Sousa (2000) found, one of the best ways of learning is to teach. Spatial management (the individual ability to understand one's body in space) and time management (the individual ability to understand the concept of time) are also crucial life skills and the last one is also very important to form memories (Damasio, 2002). The literature in neuroeducation can give the teacher some clues about how teachers can maximize students' attention (Tokuma-Espinosa, 2013).

\subsection{Teaching and Learning Science}

In the Ausubel et al. (1981) theory of the teaching and learning processes of scientific concepts, learning is seen as an internal and personal process that involves the student in the active construction of knowledge and that progress in this learning process will occur according to the interests and capacities of each one. In this sense, constructivism emerges as the epistemological foundation for a curriculum that focuses attention on the individuality of the learner, the contexts in which they learn and in the involvement in the learning process (Cachapuz, Praia, João \& Jorge, 2000; Nascimento, 2004).

On this theory the learning of scientific concepts are based on the concepts previously formed by students in their daily lives- the student is the constructor of his knowledge (cognitive constructivist theories of learning). The prior knowledge or pre-existing conceptions guide students in understanding new information, presented by teachers or books. This way, if the students' previous conceptions are articulated with the scientific version, conceptual apprehension occurs, but if they conflict with the scientific version, then conceptual change may not occur. It is important to highlight that it is difficult to learn without integrating new information into the networks of previous knowledge (Almeida, 1996; Praia, 1999).

The importance of the student prior knowledge is emphasized in research regarding physics and chemistry knowledge (Loureiro, 1993; Martins, 1993), but also biology and geology (Bettencourt \& Amaral, 1994; Faria \& Marques, 1994). In these research studies, that analyzed alternative conceptions and misconception, in science students, it was also underlined that previous learning is decisive in the new learning. That is, the previous knowledge and the degree to which it can be activated in learning situations determine new knowledge acquisitions (Almeida, 1996, 1998).

After the diagnosis of alternative conceptions, the teacher has at his disposal didactic tools that promote the student's internal reorganization of knowledge and to construct a new one (Sequeira \& Freitas, 1989, Cachapuz, 1995). One of these didactic tools is laboratory experimental or practical work.

\subsection{Experimental Work and Self-Efficacy}

One important component of the science learning process is the laboratory /experimental/practical work. It can be seen as a tool that not only values the cognitive activity of the student emphasizing the importance of previous conceptions and the meaningful learning, but also allows the conceptual change (Teaching by conceptual change), which is not only about the acquisition of new 
knowledge by the students, but demands its conceptual reorganization (Nussbaum \& Novick, 1982; Osborne \& Freyberg, 1985; Driver, 1988). As referred by Cachapuz (2000) teaching by conceptual change, underlies the use of metacognitive strategies that involve students in a continuous exercise on thinking, where the use of activities involving critical and creative thinking helps to develop higher-level skills. The teacher is no longer the central part of the classroom, but is the student's helper and the leader/mediator of the cognitive process developer. In a learning-by-building logic of knowledge, the learner's initiative is demanded and the teacher role is to be the supervisor and a guide (Almeida, 1998, 57). It is important to focus on the teaching-learning process of the learner, creating conditions for personal involvement (Praia, 1989; Almeida, 1998; Azevedo, 2004; Cappechi, 2004).

Commonly, we can say that science is created and constructed based on data that must be collected, analysed, interpreted/understand and them it can or cannot become new knowledge. Learn science is to not only understand this process, but consist in using it and develop it. In this sense, students must develop first scientific competencies which include measurement tasks, cognitive tasks (planning experiments, resources management, questioning and hypothesize theories) but also teamwork and collaborative work, which are essential to work in laboratories.

Laboratory classes improve the development of scientific competences (Etkina, Heuvelen, White-Brahmia, Brookes, Gentile, Murthy, Rosengrant \& Warren, 2006; Etkina, Karelina, \& Ruibal-Villasenor, 2008), but experimental activities such as the performance of predetermined steps (recipes) to which many school textbooks refer, often do not correspond to the expectations of students who, disliking them and resist their implementation. On the other hand, the teacher's demonstration of activities, in which the student is in a passive position, may also not promote the active involvement of the student, if it is not made in a collaborative environment of Peer Instruction (Crouch, Watkins, Fagem \& Mazut, s/d; Mazur, 2011; Lasry, Watkins, Mazur \& Ibrahim, 2013; Gok, 2012; Gok \& Gok, 2016).

The concept of self-efficacy for learning is related to students' perceptions of their ability to learn or to achieve school goals in a specific domain (Bandura, 1977). As Bandura highlighted "Perceived self-efficacy is concerned with judgments of how well one can execute courses action required to deal with prospective situations" (Bandura, 1986, 122), in this context, Zimmerman also wrote that "When students believe that they can accomplish a specific task, they demonstrate higher levels of cognitive engagement, greater interest and appreciation of that task, and hence greater motivation and more effective self-regulation learning." (Zimmerman, 1989). In this sense, Schunk reinforces saying that "Self-efficacy for learning supports motivation and guides learners to use effective self-regulatory strategies" (1996). So, to engage students in the classroom activities, the teacher must propose activities that not only motivate students but also increase their self-efficacy, making students believe in themselves.

\subsection{Experimental Work by Laboratory Stations}

The theoretical base of this classroom model/strategy is the sociocognitive psychology and neuroeducation and is supported by life skills and in metacognition highlighting the self-efficacy/motivation/attention/self-regulation. Based on theories of learning (Levine's neurodevelopmental constructs, 2002) and cognitive psychology, the beliefs of self-efficacy (Bandura, 1993), motivation, attention, self-regulation and metacognition (Pintrich \& Degroot, 1990), emerge as a strategy that promotes learning (Bzuneck, 2001).

One of the active learning tenets involves increased students' movement, which results in better attention and retention as the brain oxygenation increase (Moss \& Sholey, 1995; Wolfe, 2001; Greenleaf, 2003). So, the active learning with a hands-on approach together with the Peer instruction associated with the Collaborative work are the base of this model of practical work.

The performance of experimental classes using the laboratory station model showed to be a strategy that strengthens the students' involvement in the experimental work in the learning of Physics (Mota, 2012). The advantages or strengths of this learning model are that it promotes students' engagement in tasks, improves interpersonal relationships, allows all students to pass through the same type of laboratory experience - is democratic, is versatile in terms of physical space and materials.

\section{Methodology}

During two years students (50 students- two different classes) of a Portuguese public school, had experimental classrooms based on the laboratory stations methodology. These students started to have an experimental class with this methodology in the $8^{\text {th }}$ degree (with a median age of 13 years old), and they continued in the $9^{\text {th }}$ degree, with the same teacher. They had weekly or biweekly experimental classrooms (16 experimental classrooms each year). A formative assessment was made in each classroom, based on a worksheet file which was completed, during the class. These experimental activities were evaluated and represented $40 \%$ of the students' assessment. At the end of each year, to perceive the students' perception, related to the methodology, an anonymous survey was applied. In this paper some results will be presented.

\subsection{Experimental Work by Laboratory Stations}

An experimental class per station (45 minutes) is 
organized around four tasks (each carried out in 10 minutes, for a better operationalization) that have in common the theme, but which are distinct in the equipment / materials that they use as well as to the purpose of each, Figure $1 \mathrm{~A}$ and $\mathrm{B}$.

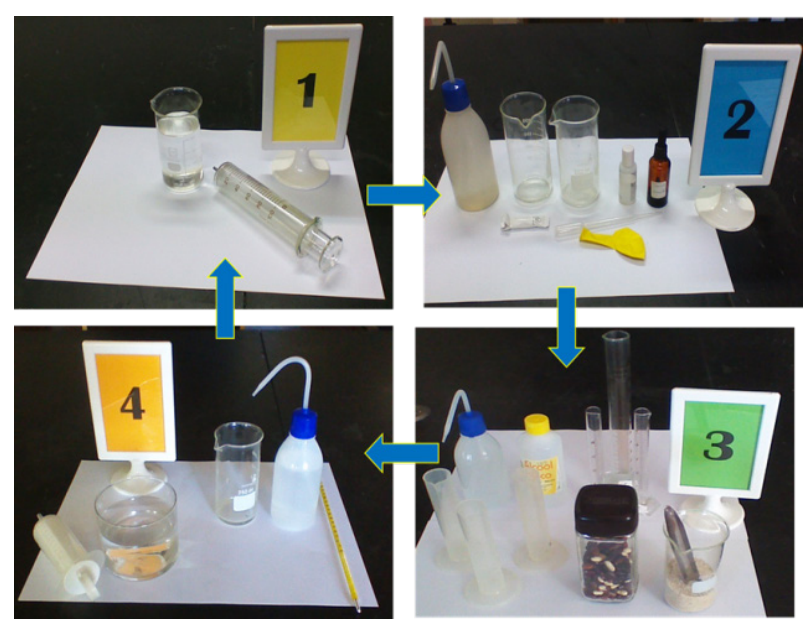

A

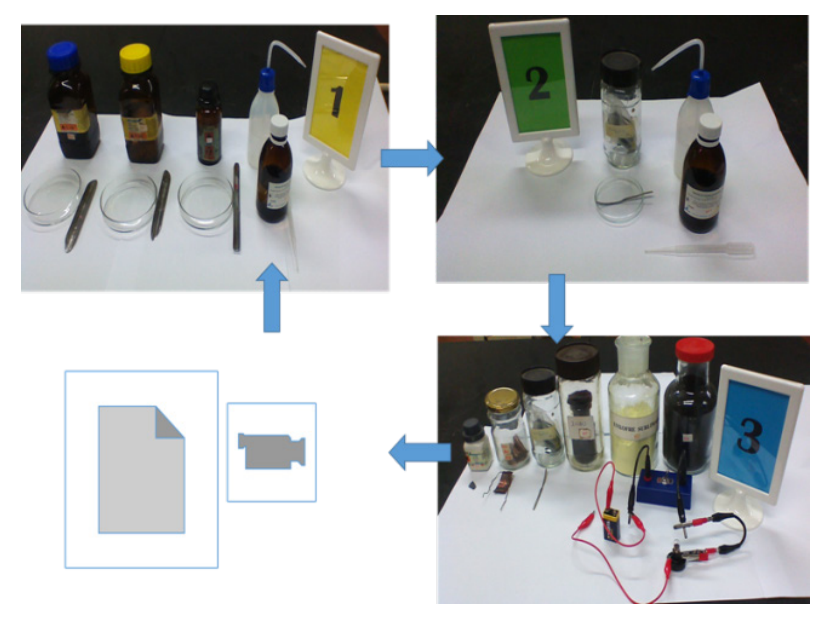

B

Figure 1. Some laboratory station's tasks proposed for students in the 8th year to study the corpuscular theory (A) and in the 9th degree, to study the Periodic table of the elements (B). Each panel represents a different task that will develop different contents and experimental goals. (A) Tasks developed by students during the classroom in the $8^{\text {th }}$ year: 1 - Analysis of the Pressure in gases and liquids; 2- Diffusion of a pigment in water and the diffusion of a perfume (that is placed in the balloon); 3-Introduction of flour into a cup with beans to perceive that there is space between particles; 4- Measure the volume of water at different temperatures (hot and cold (with ice)) and the effect of water temperature on an air balloon. (B) Tasks developed by students during the classroom in the $9^{\text {th }}$ year: 1 Reaction of alkali metals with water; 2-magnesium reaction (alkaline earth metal with water); 3- Verification of physical properties of substances, which distinguish metals from non-metals): metallic brilliance, electrical conductivity and malleability; 4- Film with experience related with the halogens
The proposed tasks/activities may involve the development of simple skills (measurements, observations, simulations, manipulation of materials) to develop more complex scientific skills (interpretation of results, planning of activities). The fact that for 45 minutes the students perform four different activities, that could be measurements or material manipulation, computational simulations, exercises, activity planning, visualization of a small film (with experimental activities) and accomplishment chemical or physical experiments, is not only a challenge for the teacher but also to the students. It should be highlighted that students only know the experiments theme in the previous lesson, to allow students to learn about it.

The teacher forms homogeneous groups (considering the knowledge level) of three students, who will perform all the activities/tasks during the lesson. To each group, the teacher delivers a lab worksheet with instructions, questions and task exploration.

The students at each lab-station, follow the specifications of the worksheets, passing to the next station after the end of the time reserved for each task (which is sonically signed with a timer). At the end of the class, the students submit the lab sheet for formative assessment. Some examples of laboratory stations in physics can be found on the Faraday project page (http://faraday.fc.up.pt) and are explored in some published papers.

The role of the teacher in this student-focused classroom is to supervise and monitor the activities of the groups and provide support and feedback to the students. The advantages of this methodology include the rationalization of materials, the versatility of tasks, the profitability of class time, personalized teaching, promotion of group work, achievement in any classroom (no need to be the laboratory), use of Kit previously prepared, applied at any level of education (these advantages are recognized by the students).

This classroom methodology implies very carefully classroom planning and management, with the teacher to delineate in detail the activities to be carried out in the next class, to articulate with the experimental classes. The experimental session with lab stations is followed by teacher correction of the laboratory worksheet. In the next classroom teacher must give feedback to the class of their laboratory work, giving recommendation and presenting a formative assessment. Students must reflect and promote if necessary self-changes in behaviour, attitudes and in strategies to learn, Figure 2. 


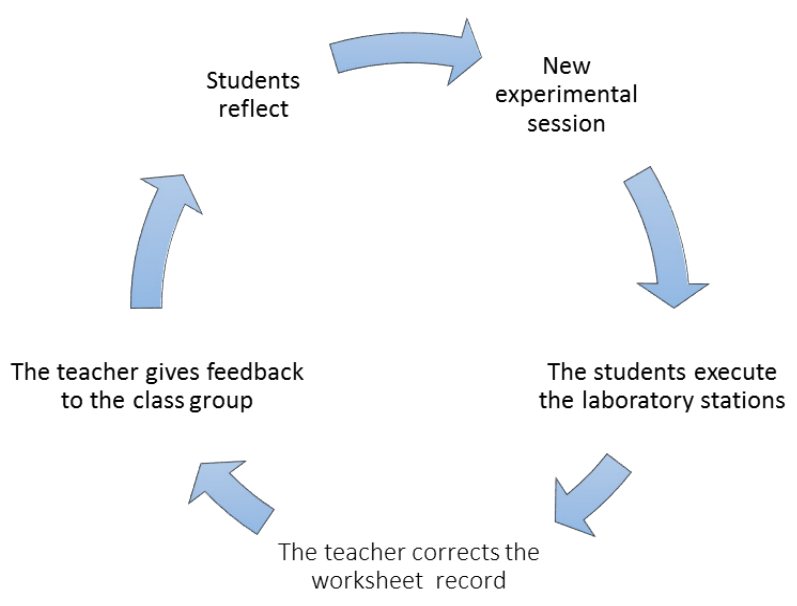

Figure 2. How it works- the principles steps of this methodology

All these levels of operationalization suppose a continuous and formative assessment with descriptive and evaluative character. In this context, feedback is essential to achieve the goal of this methodology. Students must know what they must change (attitudes, learning methodologies, habits of mind) to accomplish the tasks and learn better. They also must understand that the peer instruction and the evaluation (formative) process are instruments of learning and that the assessment that they make of the other members of the team, at the end of each period, is essential to a good teamwork (Mota, Lopes dos Santos, Ribau \& Esperto, 2016 and 2019).

\section{Results}

To understand the metacognitive and self-efficacy implications of the use of this model of experimental classes, practical classes were implemented using laboratory stations (in the field of Chemistry and Physics), regularly during two years in two classes of primary education in a Portuguese public school. For this purpose, the teacher carried out a training course titled "Fluctuation and Law of Archimedes in Basic Education: Laboratorial Stations". The first year of application of this model was carried out in collaboration with Ana Rita Mota (researcher at the University Physics Center Porto) with research work carried out and published in the area.

During these two years, laboratory charts and data sheets were created in the area of Chemistry and the existing data sheets in the area of physics (http://faraday.fc.up.pt) were adapted, taking into account the materials and the time available. Some pre-tests and post-tests in chemistry and physics contents were used to perceive the students' performance and achievements but also learning outcomes.
At the end of the first and second year of application, questionnaires were applied to the students regarding the students' perceptions of the performance of experimental activities by laboratory stations, but also regarding the teamwork and the learning process.

It was possible to verify, through surveys, that there was an increase in the number of students considering that the laboratory classes contribute to like this discipline $(82 \%$ in the $8^{\text {th }}$ year to $100 \%$ in the $9^{\text {th }}$ year).

The number of students who considered that with the division of time by different tasks during the class promoted better use of time and as a consequence, they consider the class time was more profitable. This vision, increased (57\% in the $8^{\text {th }}$ year to $72 \%$ in the $9^{t}$ h year).

The students recognize that in the laboratory classes with stations the teacher gives more individual support, but also promotes the more individualized teaching process $(84 \%$ in the $8^{\text {th }}$ year and $87 \%$ in the $9^{\text {th }}$ grade) which promotes in their opinion the autonomy but also the development of their knowledge.

For students, group learning activities and peer instruction allowed better learning $\left(77 \%\right.$ in the $8^{\text {th }}$ year and $82 \%$ in the $9^{\text {th }}$ year). As the formation of homogeneous groups by the teacher, they consider that was a fairer way of organizing students $\left(63 \%\right.$ in the $8^{\text {th }}$ year and $72 \%$ in the $9^{\text {th }}$ year).

Students consider that is essential to evaluate these activities. For them, if for lab station worksheet did not exist evaluation, they would have learned less $(52 \%$ in the $8^{\text {th }}$ year and $72 \%$ in the $9^{\text {th }}$ year).

It is important to emphasize that their perception of the importance of some classroom activities has changed over the years. They in the $9^{\text {th }}$ give a greater emphasis on laboratory classes, teacher's explanation (including feedback) and on class issues (regularly used in benchmarking. The individualized-study maintains its degree of importance (almost all students consider it very important).

It is interesting to perceive why they don't have better results, although they like classroom activities, and they are engaged in doing the tasks proposed. A question was a question regarding success in the discipline was posed "Why do you think you have not been able to get better results at physics and chemistry?" Regarding their results about the self-efficacy, they justify their results with the lack of individual study and the lack of concentration in the classroom and at home. It's important to highlight that there is an increasing percentage of students, from $8^{\text {th }}$ to $9^{\text {th }}$ degree, that refers to dislike the discipline and that perceive that they need to know how to study the discipline, Figure 3. 


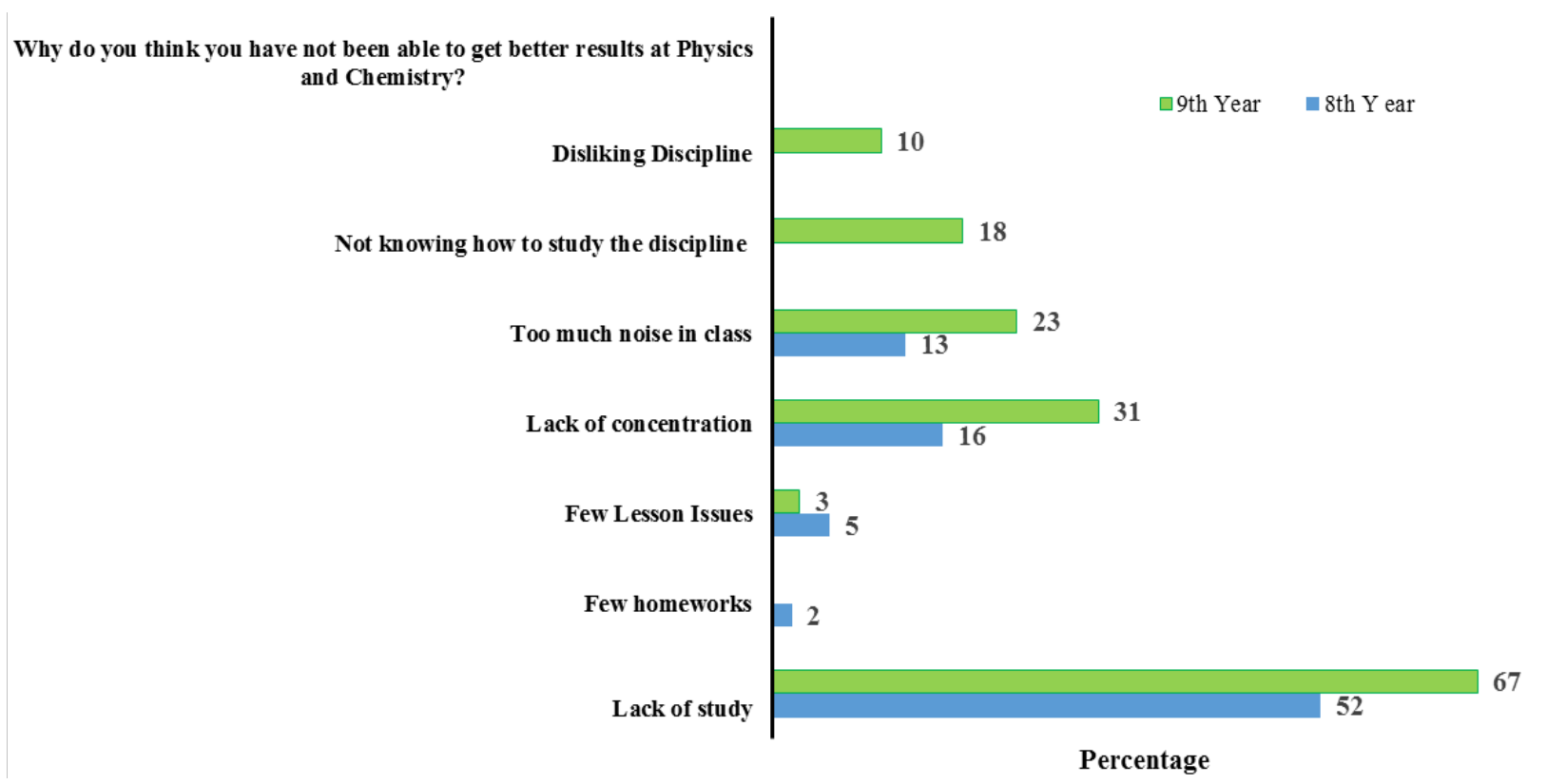

Figure 3. Percentage of students, in the 8th and 9th degree, that answered the question, "Why do you have not been able to get better results at physics and chemistry?"

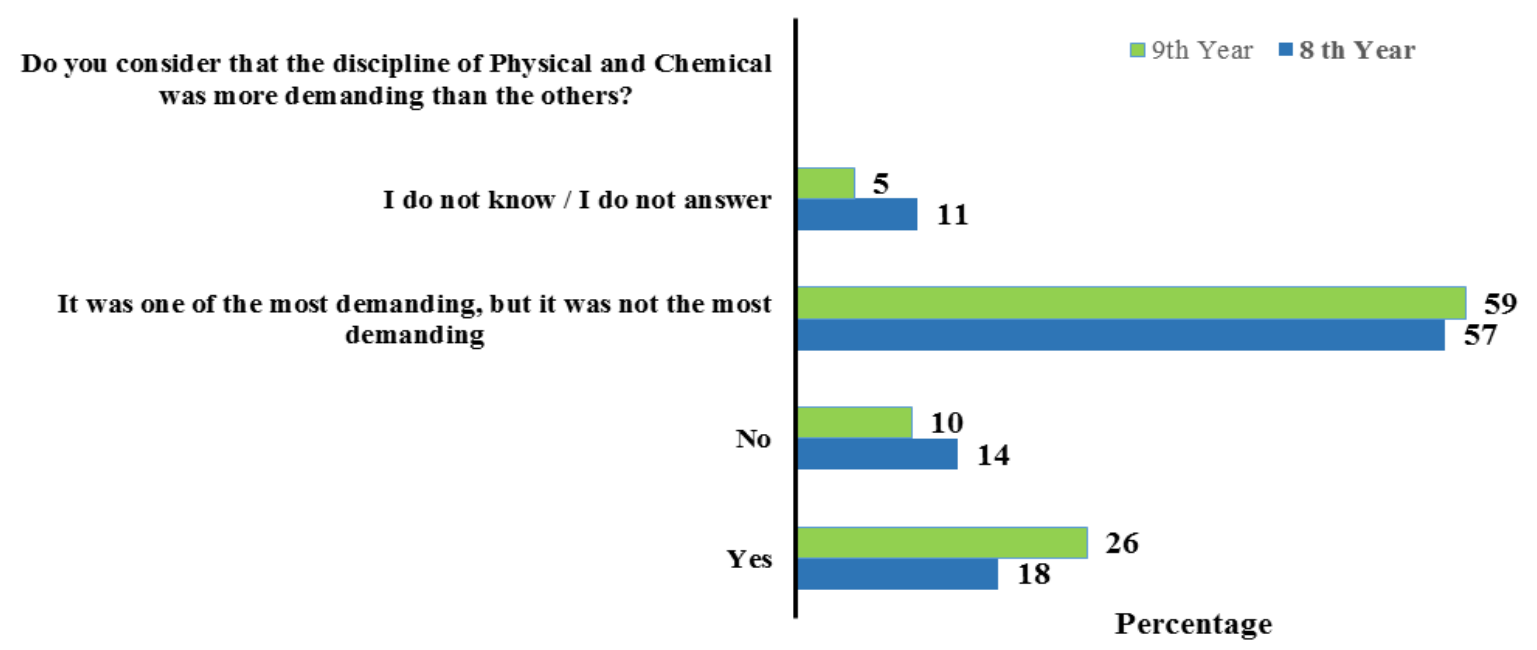

Figure 4. Percentage of students, in the 8th and 9th degree, that answered the question, "Do you consider that the discipline of physics and chemistry was more demanding than the others?"

Although the lack of study could be related to the decrease of motivation and /or self-efficacy of the students, which may mean that this model of experimental learning did not work as intended, it must be highlighted that this is not a particular problem of this students but of all students in this school. And is a problem that is difficult to resolve since is rooted in the scholar culture of these students.

We can also argue that this methodology is not appropriated to students or not good enough to train students. But as the students say in the survey, they enjoy the lab station classroom (almost $100 \%$ in both years), because is dynamic and hands-on (for $95 \%$ of the students in the 8 th year and $87 \%$ in the 9th year they prefer these classes
There is an improvement in the behaviour of the students in the classroom and greater interest and engagement of the students in the activities of the classroom. However, despite this improvement, the number of students with a level of less than or equal to three (medium level) is maintained (comparing the $8^{\text {th }}$ year with the $9^{\text {th }}$ year), increase the number of students with four, and the number of students with level five (maximum level) decrease. This decrease may be related to the increase in the number of students that refers that their chemistry and physics evaluation is due to lack of study and by the perception of an increase of the requirement in the discipline. This increase in the level of performance and demand is related to the physics and chemistry curriculum content 
itself ${ }^{1}$.once the students' must master mathematics content especially in the $9^{\text {th }}$ year, Figure 4.

Perceive the causes of the (in) success of the discipline (physics and chemistry) from the students' point of view may help to overcome the problem.

Based on the students 'responses, it was possible to perceive that this is a strategy that promotes the development of competences, increases students' motivation and their self-efficacy. However, a more in-depth study of their impact on learning will be needed. This study will be developed and deepened in the coming years.

\section{Conclusions}

This teaching-learning methodology based on sociocognitive psychology aims to increase self-efficacy, motivation and self-regulation, but also to develop scientific competencies and knowledge.

The change in the learning environment (a more friendly one), the use of fast and varied tasks (4 different lab stations and not a single 40-minute task was one of the changes to the learning environment).

Use teamwork (homogeneous groups) and peer instruction not only promote stronger connections between the students, but they also learned to listen to each other and to respect opinions different from their own. The Collaborative work between students is essential to fulfilling the aims of this methodology as well the peer instruction and active learning.

The knowledge construction with peers allows students to develop critical thinking and argumentation. Thinking based on real data, as learning tools, allowed students to obtain better results regarding scientific skills. They learn the importance of the observation, collecting data, write and organize them correctly.

Some students' change their attitudes in the classroom (started to collaborate on the tasks being engaged during the classroom, even they didn't complete all them correctly) and is visible an increased motivation (they are engage). Students usually with poor assessment in summative evaluation (writing tests) increase their achievement and motivation.

It is important to emphasize, the importance of teacher management independence and their autonomy to choose methodologies that can increase the learning in science. But, it is also important to have in mind that the teacher must follow the science core curriculum.

It's interesting to highlight that the learning process is

1The eighth-year physics and chemical curriculum focuses on chemical reactions, sound and light. The ninth year curriculum themes are motion (graphical, kinematic analysis), the motion and forces (newton's laws), and motion and energy. Also studied in the ninth year are electricity and the organization of chemical elements, the atomic structure and chemical bonding. not linear as Etkina and co-workers observed in 2006 and 2008, in higher education. Students sometimes are not so dedicated to the experimental work, and the learning outcomes only can be observed after a period of regular application of this methodology.

In this research, it was also perceived these variations too, but as Etkina recommended, to diminish this effect the experimental classroom was regular (weekly or biweekly), which allowed students to systematically train scientific skills. It was possible to observe better attitudes towards material manipulation, teamwork, and engagement in classroom activities. So, experimental work with lab stations should be applied regularly.

Tasks should be planned on the bases of the alternative conception or misconceptions, to develop scientific skills.

Experimental work by lab stations is a hands-on model and is essential for this model a continuous and formative evaluation in which teacher feedback is an essential tool. The feedback should not be only evaluative but also descriptive feedback with suggestions for improvement, questioning the coherence of the results with the theory, promoting the reflection about the activities.

Some final considerations should be made regarding the implementation of this methodology. The collaborative work among students should be implemented in all classrooms (in different disciplines), and groups should be maintained.

Individual assessment instruments should be regularly performed (fortnightly) and should be of short duration (20-25 minutes), and multiple-choice questions or open questions (problem resolution, interpretation of experimental results) maybe use (Black \& Wiliam, 1998; Ferrão, 2010). It should be noted that the laboratory worksheet held in a group should weigh in the evaluation of each student (30-40\%) since only then their teamwork is recognised, and the students perceive the result of their commitment.

\section{REFERENCES}

[1] Almeida, L. (1996) Cognition and learning: how your conceptual approach can favor cognitive performance and school achievement. Psicologia: Teoria, Investigação e Prática, I, 17-32.

[2] Almeida, L. (1998) School learning: difficulties and prevention. In Almeida \& Tavares (Orgs.). Conhecer, aprender, avaliar (pp.51-74). Porto: Porto Editora.

[3] Ausubel, D., Novak, J. \& Hanesian, H. (1980). Educational Psychology. Rio de Janeiro: Editora Interamericana.

[4] Azevedo, M. (2004). Teaching by research: problematizing classroom activities. In Carvalho, A. (Orgs.). Ensino de Ciências. Unindo a pesquisa e a prática (19-34).

[5] Bandura, A. (1977). Social learning theory. Englewood 
Cliffs, N. J.: Prentice-Hall.

[6] Bandura, A. (1986). Social foundations of thought \& action: A social cognitive theory. New Jersey: Prentice-Hall.

[7] Bandura, A. (1993). Educational Psychologist, 28, 117-130.

[8] Black, P. \& Wiliam, D. (1998).Assessment and classroom learning. Assessment in Education, 5, 7- 74.

[9] Beber, B., Silva, E. \& Bonfiglio, S. (2014). Metacognition as a learning process. Rev. Psicopedagogia, 31, 144-151.

[10] Bettencourt, T., \& Amaral, I. (1994). The plants nutrition. In F. Cachapuz (Orgs.), Ensino das ciências e formação de professores: Projecto MUTARE 3. (33-87). Aveiro: Universidade de Aveiro.

[11] Bray, S., Shimojo, S. \& O'Doherty, J. (2007). Direct instrumental conditioning of neural activity using functional magnetic resonance imaging-derived reward feedback. Journal of Neuroscience, 27(28), 7498-7507.

[12] Bruner, J. (1961). The act of discovery. Harvard Educational Review, 31, 21-32.

[13] Bzuneck, J. (2001). In the motivation of the Learner: Contributions of Contempo-rary Psychology. Boruchovitch \& J.A. Bzuneck (Org.). Petrópolis: Editora Voices, 116-133.

[14] Cappechi, M. (2004). Argumentation in a physics class. In Carvalho, A. (Orgs.). Ensino de Ciências. Unindo a pesquisa e a prática (59-76).

[15] Cachapuz, A., Praia, J., \& Jorge, M. (2000). Science Teaching Perspectives. In A. Cachapuz (Org.), Formação de Professores de Ciências. Porto: CEEC.

[16] Cachapuz, A. (1995). Science teaching for excellence learning. In: Carvalho, A (Org.), Novas Metodologias da Educação. Porto: Porto Editora, 350-385.

[17] Cachapuz, A. Praia, João \& Jorge, M. (2000). Reflection on science teaching perspectives: contributions to a new Curriculum Orientation - Teaching by Research. Revista de Educação, 9, 69-78.

[18] Crouch, C., Watkins, J., Fagen, A. \& Mazur, E. (without data). Peer Instruction: engaging students one-on-one, all at once. Research -based reform of university physics, 1-55.

[19] Damasio, A. (1994). Descartes' error: Emotion, reason and the human brain. New York: Avon Books.

[20] Damasio, A. (2002). Remembering when. Scientific American, 287(3), 66.

[21] Damasio, A. (2004). The neural basis of social behaviour. In S. Marcus, Neuroethics. Mapping the field (pp. 100-107). New York: Dana Press.

[22] Driver, R. (1988). A constructivist approach to curriculum development in Science. Enseñanza de las Ciencias, 6, 109-120.

[23] Etkina, E., Karelina, A., Ruibal-Villasenor. A. (2008) Physical review special topics. Physics educational research, 4, 020108 -1. 020108-15.

[24] Etkina, E., Van Heuvelen, A., White-Brahmia, S., Brookes, D., Gentile, M., Murthy, S., Rosengrant, D., Warren, A.
(2006). Physical review special topics-physics educational research, 2, 020103-1 - 020103-15.

[25] Faria, M., \& Marques, L. (1994). The Earth in the Solar System. In F. Cachapuz (Org.), Ensino das ciências e formação de professores: Projecto MUTARE 3 (152- 34). Aveiro: Universidade de Aveiro.

[26] Ferrão, M. (2010). E-assessment within the bologna paradigm: evidence from Portugal. Assessment \& Evaluation in Higher Education, 35, 819-830.

[27] Goswami, U. (2006). Neuroscience and education: from research to practice. Nature Reviews Neuroscience, 7, 406-413.

[28] Gok, T. (2012). The Effects of Peer Instruction on Students' Conceptual Learning and Motivation. Asia-Pacific Forum on Science Learning and Teaching, 13, Article 10.

[29] Gok, T. \& Gok, O. (2016). Peer instruction in chemistry education: Assessment of students' learning strategies, conceptual learning and problem solving. Asia-Pacific Forum on Science Learning and Teaching, 17, Article 9.

[30] Greenleaf, R. (2003). Motion and emotion in student learning. Education Digest, 69, 37-42.

[31] Inchausti de Jou, G. \& Sperb, T. (2006). Metacognition as a regulatory strategy for learning. Psicologia: Reflexão e crítica, 19, 177-185.

[32] Lasry, N., Watkins, J., Mazur, E. \& Ibrahim, A. (2013). Response times to conceptual questions. American Journal Physics, 81, 703-706

[33] LeDoux, J. (1996). The emotional brain: The mysterious underpinnings of emotional life. New York: Simon \& Schuster.

[34] LeDoux, J. (2000). Emotion circuits in the brain. Annual Review of Neuroscience, 23(1), 155-184.

[35] Levine, M. (2000). A mind at a time. New York: Simon \& Schuster.

[36] Loureiro, M. (1993). Alternative Conceptions (misconceptions) in Physics: electricity basics concepts,. In F. Cachapuz (Coord.), Ensino das ciências e formação de professores: Projecto MUTARE 2 (39-74). Aveiro: Universidade de Aveiro.

[37] Martins, I. (1993). Misconcepts about energy in Chemistry. In F. Cachapuz (Coord.), Ensino das ciências e formação de professores: Projecto MUTARE 2 (7-38). Aveiro: Universidade de Aveiro.

[38] Mazur, E. (1997) Peer Instruction: a user's manual. Prentice Hall Inc., Upper Saddle River, New Jersey.

[39] Moss, M. \& Scholey, A.B. (1995). Oxygen administration enhances memory formation in healthy young adults. Psychopharmacology 124, 255-260.

[40] Moreira, M. \& Masini, E. (1982). Meaningful Learning: David Ausubel's Theory. São Paulo: Editora Moraes.

[41] Mota, R. (2012). Practical test of the Movement Core knowledge in teaching of Physics in Portugal. Phd Thesis, University of Porto.

[42] Mota, R., Lopes dos Santos, J., Ribau, I., Esperto, P. (2016). 
Peer and self-assessment: a mathematical model to improve the students' accountability in lab Stations model. 2nd World Conference on physics Education, Brazil.

[43] Mota, R., Lopes dos Santos, J., Ribau, I., Esperto, P. (2019). Peer and Self-assessment: a mathematical model to improve the students' accountability in lab stations model. International Journal of Physics and Chemistry Education, 1, 7-11.

[44] Nascimento, V. (2004). The nature of scientific knowledge and science education. In Carvalho, A. (Orgs.). Ensino de Ciências. Unindo a pesquisa e a prática.(35-18).

[45] Nussbaum, J. \& Novick, S. (1982). Alternative frameworks, conceptual conflict and accommodations: Toward a principled teaching strategy. Instructional Science, 11, 183-200.

[46] Osborne, J, \& Freyberg, P. (1985). Learning in science: The implication of children's science. London: Heinemann Publishers.

[47] Pintrich, P. R., \& De Groot, E. V. (1990). Motivational and self-regulated leaning components of classroom academic performance. Journal of Educational Psychology, 82, $33-40$.

[48] Praia, J. F. (1989). Science teacher education and specific didactics: A changing perspective on teaching conceptions. Revista Portuguesa de Educação, 2 (3), 141-146.

[49] Praia, J. (1999). Report of the Geology Didactics course. Porto: Universidade do Porto.

[50] Ribeiro, C. (2002). Learn to learn. Some considerations about teaching study strategies. Mathesis, 11, 275-286.

[51] Reeve, J. (2004). Understanding motivation and emotion (4th edition). New York: Wiley \& Sons.

[52] Rosa, C. (2014) Metacognition in Teaching of Physics: from design to implementation. Universidade de Passo Fundo. Passo Fundo.

[53] Schunk, D. (1996). Self-efficacy for learning and performance. Paper Presented at the Annual Conference of the American Educational Research Association, New York.

[54] Sequeira, M. \& Freitas, M. (1989) "Conceptual Maps" and science teaching and learning. Revista Portuguesa de Educação, II (3), 107-116.

[55] Sousa, D. (2000). How the brain learns. Thousand Oaks, CA: Corwin Press.

[56] Tavares, J. \& Alarcão, I. (1992). Psychology of development and learning ( $4^{\mathrm{a}}$ ed.). Coimbra: Livraria Almedina.

[57] Tokuhama-Espinosa. (2008). The scientifically substantiated art of teaching: a study in the development of standards in the new academic field of neuroeducation (mind brain and education science). A PhD dissertation, Capella University, June 2008.A2

[58] Tokuhama-Espinosa. (2013). Making classroom Better. 50 practical application of mind brain and education. W. W. Norton \& Company.

[59] Vasconcelos, Clara, Praia, João Félix, \& Almeida, Leandro
S. (2003). Learning theories and science teaching / learning: from instruction to learning. Psicologia Escolar $\mathrm{e}$ Educacional, 7 (1), 11-19.

[60] Zimmerman, B. J. (1989). Model of self-regulated learning and academic achievement. In B. J. Zimmerman \& D. H. Schunk (Eds.), Self-regulated learning and academic achievement: Theory, research and practice (pp. 17). New York.

[61] Wolfe, P. (2001). Brain Matters: Translating research into classroom practice. Alexandria, VA: Association for Supervision and Curriculum Development. 